\title{
Intercultural Communication in Borobudur Homestay Village
}

\author{
Annis Azhar Suryaningtyas ${ }^{1 *}$, Lintang Muliawanti ${ }^{1}$ \\ ${ }^{1}$ Department of Communication Science, Universitas Muhammadiyah Magelang, Magelang, Indonesia \\ *Corresponding author. Email: annis.azhar@ummgl.ac.id
}

\begin{abstract}
Borobudur is one of 10 new Bali programs. Therefore, it is probable that residents around the tourist sites in Borobudur have the opportunity to interact with foreign tourists. With differences in cultural and linguistic backgrounds, it certainly raises the dynamics of intercultural communication between local communities, homestay owners and tourists. This research was conducted to see the process of intercultural communication that occurred in the Borobudur Home stay Kampung community with foreign tourists visiting as an initial illustration of the community's readiness to face the priority tourism program. This research uses a qualitative method with a case study approach. Data collection techniques using semi-structured interviews. The technical analysis of this research data uses the process of interaction analysis. While the technical validity of the data using data triangulation. The results show that there is anxiety experienced by homestay managers when interacting with foreign tourists. Anxiety has a different dose. The level of anxiety and uncertainty that tends to be above the upper and lower limits causes homestay managers to choose to limit their interactions with foreign tourists. While homestay managers with a degree of anxiety and uncertainty in the middle position tend to be ideal because it fosters motivation on homestay managers to interact and learn to improve their skills in foreign languages.
\end{abstract}

Keywords: intercultural communication, inter-cultural anxiety, tourism priorities

\section{INTRODUCTION}

The New Bali 10 Program is one of the priority programs of the Ministry of Tourism which is expected to accelerate development to bring in 20 million foreign tourists. One of the destinations of Bali Baru is Borobudur, which is located in Magelang, Central Java. The Ministry of Tourism also focuses on the development of tourism ecosystems (framework 3A), namely Attractions, Accessibility, and Amenity to support the development of tourism destinations, [7].

Based on this, the availability of accommodation or homestay becomes an important part as an element of supporting the completeness of facilities and infrastructure in tourism destinations. According to the Head of the 10 New Bali Development Acceleration Team, Hirmansyah, revealed the Development of Tourism and Homestay Villages were being given attention in 10 New Bali to support the attractions and amenities of their respective tourist areas [7].

According to Eril, Regent of Simeulue, the existence of a homestay is very much needed to support the accommodation of tourist villages. Meanwhile, the Head of the Rural and Urban Tourism Acceleration Team, Vitria Ariani, stated the existence of homestays has an important role in providing authentic experiences to tourists. Thus, an active role of tourism awareness groups is needed as the driving force [9].

However, the existence of homestays in a number of tourism priority areas still needs improvement. Mainly related to management by the local community. According to Anneke, the Chairperson of the Acceleration of Tourism Village Homestay Development, Kemenpar, added that the limited knowledge of the village community is one of the major tasks of the Ministry of Tourism and Culture to improve this tourism program to be more optimal. The existence of limited knowledge can be the initial data that the need for compliance "readiness" of the surrounding community in receiving guests (foreign tourists). Therefore, he felt the need to provide assistance and outreach to 10 priority national tourism areas [6].

The limited human resources in managing this homestay also occurs in the Ngaran II homestay village. Such as limitations in the readiness of citizens to receive foreign guests. Both in terms of cultural knowledge and foreign language skills. In addition, unfair competition is still found among homestay managers. There is no standardization of the same facilities.

Concerned about the situation, a citizen took the initiative to make Ngaran II Village a homestay village. The goal is that the management of homestay villages is more organized.

This then becomes important when it is associated with the government's target of wanting a foreign tourist visit of 20 million. Because of that, from July to September in Ngaran II Homestay Village, there were many foreign tourists visiting. As happened at the Anugrah, Willy, Cahaya and Dua Pintu homestay.

The arrival of this foreign tourists could not help making communication between cultures in the Ngaran II homestay village. Communication between effective cultures can bridge the creation of tourism based on the experience of 
tourists of local wisdom. However, the limited human resources of homestay managers are still an obstacle to achieving these goals. Therefore, there is a need for research relating to the readiness of homestay managers to deal with foreign tourists based on cultural communication.

Research related to intercultural communication was also explained by Arkadiusz and his colleagues in a study entitled Cultural Differences, Stereotypes and Communication Needs in Intercultural Communication in a Global Multicultural Environment: The Employees' Perspective. In the Journal of Intercultural Communication; Göteborg Iss. 43, (Mar 2017): N_A. This study discusses the personal opinions of Chinese employees working in a multicultural environment regarding the relationship between cultural diversity and the efficacy of their communication in a multicultural environment. The aim is to better understand the relationship between cultural background and efficient business communication. This research uses survey method. The results show that even if respondents state the negative effects of cultural differences on communication, they also manifest a positive attitude towards intercultural interaction. In addition, ignoring or even disrespecting cultural values that differ from interactants is considered a basic obstacle in intercultural communication, and these obstacles can be avoided when different cultural backgrounds are respected. Although cultural differences are considered to hamper respondents' performance and are often a source of dissatisfaction, they do not prevent them from entering into intercultural communication [2].

Another fact related to the importance of examining the phenomenon of intercultural communication is seen in research conducted by Mayra Rodriguez and his colleagues in the journal Journal of Intercultural Communication; Göteborg Iss. 49, (Mar 2019): 1. Intercultural communicative competence (ICC) is an important tool in teaching and learning foreign languages. The main purpose of this article is to propose a number of tasks to improve intercultural communicative competence in English Language Courses at the Universidad Central "Marta Abreu" de Las Villas, Santa Clara, Villa Clara, Cuba. Thus, this article provides some theoretical basis for concepts related to culture, communicative competence, intercultural communication and intercultural communicative competence. The proposed assignment can be adapted to different contexts, taking into account the needs and interests of students. They apply four language skills at once, combining communicative competence and intercultural communicative competence, two aspects that make students a perfect mediator in the process of learning foreign languages [8].

Intercultural communication competence is also needed in the health sector. This was revealed by Karabuga et al in a study entitled Intercultural Communication Competence of Nurses Providing Care for Patients from Different Cultures. This research was conducted with nurses who provide care for intercultural populations with the aim of determining the intercultural communication competencies of nurses who provide care for patients from different cultures. This research uses survey method. Nurses have high Intercultural Awareness, Intercultural Sensitivity and Intercultural Effectiveness scale scores. It was found that the scores obtained from Intercultural Awareness, Intercultural Sensitivity and Intercultural Effectiveness scales did not show differences according to the descriptive characteristics of nurses [10].

In Indonesia, there is also a trend of intercultural communication research. Like the research revealed by Anwar and Cangara, entitled The Intercultural Communication Barriers of Marriage and Divorce Between Java and Papua Ethnics in The City of Jayapura (Conflict Management Strategy in Husband and Wife Interpersonal Relationship). The research aims (1) to identify communication barriers between cultures of Javanese ethnic groups and Papuans who are still in marriage and divorced couples, (2) analyze conflict management strategies in the interpersonal relationships of Javanese ethnic couples with Papuans in addressing existing conflicts. The study uses an interpretive approach with qualitative research methods. This research shows that open communication between a good married couple is not necessarily able to reduce the intensity of conflict in the process of escalation of relationships in marriage. The style of communication between Javanese and Papuans (controlling, aggressive, coercive, dominating and racist) contributes to determining the emergence of conflict. The main solution is that they form strong bonds of commitment and the need for an understanding of diversity [1].

Other research has also been carried out by Melyana Gozali with the title Anxiety Uncertainty Management (AUM) East Timorese Teenagers in Malang City in Building a Social Environment. This research was conducted to examine the phenomenon of intercultural communication, with anxiety uncertainty management (AUM) of East Timorese adolescents who migrated in Malang. The results of this study indicate three things that cause both have different ways of behaving and respond when experiencing anxiety uncertainty, namely parenting patterns, character, and trauma experience. The way management is carried out by East Timorese youth is by knowing who they are and convincing themselves to behave according to their selfimage by talking to themselves. Secondly build selfconfidence, great support from parents is used as motivation and to instill positive thoughts. Third, build relationships with new people. Finally, learning to understand culture / environment [3].

The five studies above have differences with this research in the field of research studies. If the first and second studies together examine the intercultural communication that occurs in an organization. Meanwhile, the third study examined communication between cultural backgrounds in the field of health studies. Whereas the fourth and fifth studies focus on the field of relationship studies. In contrast to this research explore the communication between cultures that occur in the field of tourism studies.

Furthermore, related to the method, the first to third studies using survey methods. Whereas the fourth and fifth studies used qualitative methods. This qualitative method is the same as the method used in the ongoing research this time. Thus, this phenomenon becomes interesting when examined in terms of communication related to intercultural communication that occurs between homestay managers and foreign tourists in the homestay village of Borobudur. In terms of managing their anxiety and uncertainty when 
interacting with people of different cultures. As a form of illustration of the readiness of citizens when "host" for foreign tourists. This Phenomena will then be provided with uncertainty and anxiety management theory.

The theory expressed by William Gudykunst was inspired and continued Charles Berger's thoughts on the theory of uncertainty reduction Theory. In Gudykunst's view the relationship between people with different cultures is the same as communicating with strangers. Gudykunst continued, our interaction with people who are "different" from us will lead to the emergence of anxiety and uncertainty about the interactions we will carry out [5]. Uncertainty reduction is a cognitive process in which individuals try to understand situations by making proactive predictions about other attitudes, values, feelings, beliefs and behavior and by creating retroactive explanations that make sense for another people's behavior. Individuals are motivated to reduce uncertainty when they: (1) anticipate future interactions with others, (2) others can meet individual needs or can manage rewards or punishments, and or (3) others behave in deviant or unexpected ways [4]. In this theory there are concepts of uncertainty and anxiety. According to Gudykunst, Uncertainty, is related to the needs and desires that can be predicted. While anxiety is a feeling of worry. He further explained, uncertainty and anxiety are important when we communicate with people of different cultures. Because, with these two concepts keep us focused on something "important" in our interactions. Meanwhile, the focus here does not lead to the feeling of worry but rather to the understanding of differences in recognition and ignorance [5].

Gudykunst explained that there are maximum and minimum limits in the sense of uncertainty and anxiety that make our intercultural interactions productive, and we need that to achieve effective communication. But not a clear measurement line to describe the threshold of uncertainty and anxiety that can produce problems or problems. In his explanation, Gudykunst believes that this is because each individual has different levels of uncertainty and anxiety [5].

In this theory, Gudykunst revealed three assumptions. First, if the level of uncertainty exceeds the upper limit of an individual, the individual is not feeling confident when meeting intercultural interactions, and therefore has the possibility to avoid communication. The same applies to someone experiencing anxiety, he will feel nervous and less likely to choose to communicate between cultures [5].

Secondly, just as if an individual's sense of uncertainty is at the lower limit, the motivation to communicate between cultures will be lost. Because the individual will feel "enough" to know. Similarly, if an individual does not feel anxiety it will not foster a sense of attention or desire to try to interact with individuals with different cultures [5].

In the third point, Gudykunst writes an ideal condition related to the boundary of uncertainty and anxiety, which is located between the upper and lower limits of each individual's condition. According to him, this can foster motivation in communicating between cultures and adopting uncertainty-reduction strategies [5].

Rather, the key concept of this theory is effective communication and attention. Effective communication refers to the exchange of messages that results in maximum understanding. Communication with different cultures will seem difficult, because we use values, frames of reference, and our communication styles to understand the behavior of others. Meanwhile mindfulness or (mindfulness) of meaningful communication refers to our awareness of our communication style and strategy. Mindfulness is important to avoid our way of thinking which is oriented to values, frames, and our own communication style. Then, leading us to be more aware of the "differences" in interactions between cultures. Thus, it opens up opportunities for perspective to adapt to values, regulations, and other cultural identities. Finally, it can be used to help us carry out management of uncertainty and anxiety [5].

The process of Uncertainty and Anxiety Management is influenced by three factors namely, group identity, connections with strangers, and culture variability. Group identity refers to our ability to identify differences in the cultural backgrounds of our interlocutors. Meanwhile, Connection with strangers refers to tolerance of ambiguous meaning in the interactions between cultures we are facing. As for cultural variability, it refers to the four dimensions of culture, namely, individual-collective, power distance, uncertainty avoidance, and masculinity-femininity. These three factors are used to identify the initial process of uncertainty and anxiety management [5].

Gudykunst believes anxiety and uncertainty are related to the nature of communication, behavior, and patterns combined with what we do when communicating with culturally diverse individuals who have an impact on our communication effects.

This theory was also extended by James Neulip, he argues that fear in communication and ethnocentrism have a negative relationship on uncertainty reduction and satisfaction in communication. This is the same as expressed by Gudykunst that his theory shows that there are additional factors that make uncertainty and anxiety can cause negative effects in effective communication [5]

\section{RESEARCH METHOD}

This study using a descriptive qualitative approach. Because, in this study the data to be sought is in the form of descriptive information related to uncertainty and anxiety management that occur in intercultural communication in Borobudur homestay village.

To get the data selection of informants is done by using a purposive technique. There are two informant criteria chosen, the first is the homestay village manager. second, homestays that have had the experience of receiving foreign tourists.

Meanwhile, the process of finding data in this study was explored by interview and observation techniques. Then, for data validity techniques using source triangulation. Finally, the process of analyzing the data of this study uses data analysis of interactions that begins with the process of data reduction, data presentation, and drawing conclusions. 


\section{RESULTS}

Visits of foreign tourists to the village of Borobudur Homestay crowded occurred in July, August, and September. Therefore, it can be identified that there is intercultural communication in the Borobudur Homestay Village when the foreign tourist visiting season arrives. From 21 Borobudur Homestay Village members, 4 Homestays were found that have had the experience of receiving foreign tourists. They are Homestay Anugrah Borobudur, Homestay Willy, Homestay Cahaya, and Dua Pintu Doors.

Anugrah Borobudur Homestay has received foreign guests from, for example, Germany, Canada, Italy, Japan and Korea. Then, Willy Homestay once received foreign guests from France and Japan. Meanwhile, Homestay Light and Dua Pintu Homestay claimed not to know the origin of foreign guests visiting their place.

In dealing with foreign tourist guests they experience different uncertainty and anxiety. For example, in the homestay Anugrah uncertainty and anxiety are in the ideal category. Meanwhile for Willy uncertainty and anxiety homestay they are at the lower limit. Meanwhile, Homestay Light and Dua Pintu Homestay are at a high level of uncertainty and anxiety.

In homestay Anugrah can be considered ideal because it has a positive impact on the homestay manager. He can identify the existence of "distance" between the manager of the homestay and foreign tourist guests, if there is no interaction when guests stay. The vacancy can be filled if he has the ability to speak a foreign language (international language or English) as a liaison between the host and guests. Therefore, he became motivated to learn a foreign language. Another motivation that appears is that managers try to provide an "experience with nuances of local wisdom" to foreign tourist guests. The experience was in the form of introducing them to the local life of the Magelang community. Thus, managers are encouraged to create effective communication and mindfulness. This is evident in the attitude of the Manager trying to establish good relations with foreign tourist guests and know related to their cultures. For example, foreign tourists are more likely to have high privacy and are always on-time.

Meanwhile, at Willy's homestay, it can be said that the level of uncertainty and anxiety is low because they feel "mediocre" when accepting foreign tourists. The low sense of worry and anxiety arises because their frame of reference to foreign tourists is fixed by three factors. First, vulnerable short stay time. Second, the presumption of foreign tourist time spent on the streets. Third, all important agreements as an objective of effective communication from the homestay manager and foreign tourist guests can be completed online. These three aspects give rise to a sense of "enough" and therefore do not give motivation to not too much for them to open the accuracy of interaction. This was followed by their lack of curiosity to learn the cultural background of foreign tourists visiting the homestay. This comfortable condition has made managers unable to identify that it is necessary to create an "interesting experience" for foreign tourists visiting their homestays. Thus, their interactions are few.
In contrast to the Light and Two Door Homestay, their level of uncertainty and anxiety is quite high. This is caused by a bad experience factor related to the attitude of foreign tourist guests who are not polite and do not maintain cleanliness. So that appears fear in communicating with foreign tourist guests. And make the manager of the two homestays avoid guests from foreign tourists.

\section{CONCLUSION}

\subsection{Conclusion}

Based on the management of anxiety and uncertainty that occurs in intercultural communication in the Borobudur homestay village can be classified into three namely upper limit, medium limit and lower limit. The dynamics of managing anxiety and uncertainty on host interactions with foreign tourists can be seen from the readiness of human resources and facilities.

The social class of the homestay manager is very influential. Homestay managers with high economic background and knowledge tend to be able to communicate more effectively with foreign tourists. There is motivation to explore the cultural background of foreign tourists who come, there is an attitude of tolerance and will respect cultural differences by providing privacy space. This pattern of interaction with anxiety and uncertainty management at moderate levels allows foreign tourists to feel more comfortable. Homestay owners with a level of human resources and middle economic class, tend to be at the lower limit, with a more apathetic character. They feel the interests of owners and foreign tourists are only limited to transactional interactions, and are not important to interact further. Whereas homestay managers with low human and economic resources are at the upper limit of anxiety and uncertainty. They tend to avoid more interaction with foreign tourists. There is a high level of anxiety, due to a feeling of power distance. That feeling of weakness makes anxiety grow stronger. This is the dynamics of the problem in the homestay village.

There is no standardization of human resource readiness so there is a gap between homestay classes, which is influenced by the social class of homestay managers. With effective interaction, those who are ready in terms of resources will be able to provide better experiences and services for foreign tourists, while homestay managers with middle to lower social classes tend to be difficult to develop because of the inability to adapt to the development patterns and needs of tourists. Concerned that this continuous pattern will crush small homestays because it is difficult to develop due to high anxiety. Therefore, the role of the government, academics, the private sector, and the media is needed to improve the welfare of the community through the tourism sector. Especially in aspects of human resource development, both mindset and hospitality skills. 
intercultural adaptation context. Communication Quarterly; University Park Vol. 46, Iss. 3, (Summer 1998): 309-325. DOI:10.1080/01463379809370104

Cultivating a sense of uncertainty and anxiety in bringing it naturally and its management efforts towards positive impacts such as creating interesting experiences for foreign tourists who have stayed overnight in a homestay. This interesting experience is expected to be a plus in the Borobudur homestay village. As an indication of the readiness of the community in participating in developing the tourism sector. Unique identity that can be started from the readiness of the community in accepting foreign guests.

\section{REFERENCES}

[1] Anwar, Rostini, and Hafied Cangara. "Rintangan Komunikasi Antar Budaya Dalam Perkawinan Dan Perceraian Etnis Jawa Dengan Papua Di Kota Jayapura (Suatu Strategi Manajemen Konflik Dalam Hubungan Interpersonal Pasangan Suami Istri)." KAREBA: Jurnal Ilmu Komunikasi 5.2 (2017): 273-285.

[2] Gut, Arkadiusz dkk. 2017. Cultural Differences, Stereotypes and Communication Needs in Intercultural Communication in a Global Multicultural Environment: The Employees' Perspective. Journal of Intercultural Communication; Göteborg Iss. 43,_(Mar 2017): N_A.

[3 ]Gozali, Melyana, Judy Djoko W. Tjahyo, and Titi Nur Vidyarini. "Anxiety Uncertainty Management (AUM) Remaja Timor Leste di Kota Malang dalam Membangun Lingkungan Pergaulan." Jurnal eKomunikasi 6.2 (2018).

[4] Hammer, Mitchell R dkk. 1998. A test of anxiety/uncertainty management theory: The
[5] Littlejohn. Teori of Humman

Communication.USA:Waveland Perss

[6] Nasution, Dedy Darmawan.2019. Genjot Pariwisata, Kemenpar Benahi Bisnis Homestay Daerah.

Republika:https://republika.co.id/berita/ekonomi/korpor asi/pt6nq4423/genjot-pariwisata-kemenpar-benahibisnis-emhomestayem-daerah. Diakses pada 20/11/2019 pukul 22.45

[7] Pratama, Akhdi Martin.2019. Sektor Pariwisata Ditargetkan Raup Devisa Rp 246 Triliun di 2019.kompas.com: . Dikases pada 29 Oktober 2019 pukul 15.15 .

[8] Ruiz, Mayra Rodriguez dkk. 2019. Improving the Intercultural Communicative Competence of English Language Students. Journal of Intercultural Communication; Göteborg Iss. 49, (Mar 2019): 1.

[9] Widiarini, Anissa Dea.2019. Homestay Berpotensi Dukung Pengembangan Desa Wisata.kompas.com: https://ravel.kompas.com/read/2019/07/10/113000127/ homestay-berpotensi-dukung-pengembangan-desawisata?page $=$ all. Diakses pada 29 Oktober pukul 15.15

[10] Yakar, Hatice Karabuga dkk. 2018. Intercultural Communication Competence of Nurses Providing Care for Patients from Different Cultures. International Journal of Caring Sciences;

Nicosia Vol. 11, Iss. 3, (Sep-Dec 2018): 1396-1407. 